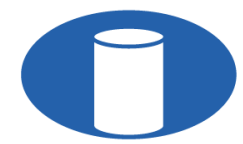

IBRACON Structures and Materials Journal

Revista IBRACON de Estruturas e Materiais

ORIGINAL ARTICLE

\title{
Eco-efficient concrete, optimized by Alfred's particle packing model, with partial replacement of Portland cement by stone powder
}

\section{Concreto ecoeficiente, otimizado pelo modelo de empacotamento de Alfred, com substituição parcial do cimento Portland por pó de pedra}

\author{
Heloisa Fuganti Campos ${ }^{\mathrm{a}}$ (D) \\ André Lucas Bellon ${ }^{\mathrm{a}}$ \\ Eduardo Reis de Lara e Silva ${ }^{\mathrm{a}}$ (D) \\ Maurício Villatore Junior ${ }^{\mathrm{a}}$ (i)
}

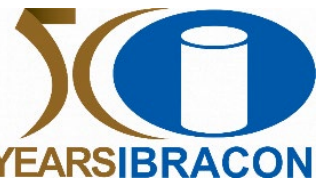

${ }^{a}$ Universidade Federal do Paraná - UFPR, Departamento de Construção Civil, Curitiba, PR, Brasil

Received 08 April 2021

Accepted 11 August 2021

\begin{abstract}
The partial replacement of clinker by complementary cementitious materials can significantly contribute to the reduction of carbon emissions in the production of concrete. Another alternative to reduce these emissions is to increase the efficiency of the concrete, achieving higher compressive strength with lower consumption of cement. Particle packing models are efficient tools to optimize the composition of the matrix and contribute to the production of more eco-efficient concretes. In this context, the objective of the present study is evaluating the production of concretes with partial replacement of cement by stone powder, optimized by Alfred's particle packing model, seeking to reduce cement consumption and $\mathrm{CO}_{2}$ emissions per $\mathrm{MPa}$ of compressive strength. The replacement content of cement by stone powder was $20 \%$ by mass (equivalent to $22.4 \%$ by volume). Concretes were produced with different distribution factor (q) - $0.37 ; 0.21 ; 0.45$ - to verify the influence of fines on the flow between particles and on the efficiency of the produced concrete. The analyses were carried out in terms of properties in the fresh state, hardened state, and sustainability parameters (cement consumptions and $\mathrm{CO}_{2}$ emissions). The application of the proposed method resulted in a higher compressive strength than the expected for the water/cement ratio used (0.5). The most efficient concrete reached the compressive strength of $68 \mathrm{MPa}$ with $240 \mathrm{~kg} / \mathrm{m}^{3}$ of cement, which represents $3.5 \mathrm{~kg}$ of cement $/ \mathrm{m}^{3} / \mathrm{MPa}$ and $3.1 \mathrm{~kg}$ of $\mathrm{CO}_{2} / \mathrm{m}^{3} / \mathrm{MPa}$, a value below the references found in the literature for conventional concretes. Therefore, the proposed method allows to produce more eco-efficient concrete, contributing to the use of waste and reducing $\mathrm{CO}_{2}$ emissions.
\end{abstract}

Keywords: particle packing, Alfred model, stone powder, eco-efficient concrete.

Resumo: A substituição parcial do clínquer por adições pode contribuir de maneira significativa na mitigação da pegada do carbono dentro da cadeia produtiva do concreto. Outra alternativa para reduzir essas emissões é o aumento da eficiência do concreto, atingindo maiores resistências com menores consumos de cimento. Modelos de empacotamento de partículas são ferramentas eficientes para otimizar a composição da matriz e contribuir para a produção de concretos mais ecoeficientes. Nesse contexto, o objetivo do presente estudo é avaliar a produção de concretos com substituição parcial do cimento por pó de pedra, otimizados pelo modelo de empacotamento de partículas de Alfred, buscando reduzir o consumo de cimento e as emissões de $\mathrm{CO}_{2}$ por MPa de resistência à compressão. O teor de substituição do cimento Portland por pó de pedra foi de $20 \%$ em massa (equivalente a $22.4 \%$ em volume). Foram produzidos traços com diferentes módulos de distribuição (q) - 0,$37 ; 0,21 ; 0,45$ - a fim de verificar a influência dos finos no escoamento entre as partículas e na eficiência dos concretos produzidos. A análise foi realizada em termos de propriedades no estado fresco, estado endurecido e parâmetros de sustentabilidade (consumo de cimento e emissões de $\mathrm{CO}_{2}$ ). A aplicação do método proposto permitiu obter resistências superiores às esperadas para a relação água/cimento utilizada $(0,5)$. $\mathrm{O}$ traço mais eficiente atingiu a resistência à compressão de $68 \mathrm{MPa}$ com $240 \mathrm{~kg} / \mathrm{m}^{3}$ de consumo de cimento, o que representa $3,5 \mathrm{~kg}$ de cimento $/ \mathrm{m}^{3} / \mathrm{MPa}$ e $3,1 \mathrm{~kg} \mathrm{de} \mathrm{CO}_{2} / \mathrm{m}^{3} / \mathrm{MPa}$, valores abaixo das referências encontradas

Corresponding author: Heloisa Fuganti Campos. E-mail: heloisacampos@ufpr.br

Financial support: None.

Conflict of interest: Nothing to declare.

This is an Open Access article distributed under the terms of the Creative Commons Attribution License, which permits unrestricted use, distribution, and reproduction in any medium, provided the original work is properly cited. 
na literatura para concretos convencionais. Portanto, o método proposto permite produzir concretos mais ecoeficientes, contribuindo para a utilização de um resíduo e reduzindo as emissões de $\mathrm{CO}_{2}$.

Palavras-chave: empacotamento de partículas, modelo de Alfred, pó de pedra, concreto ecoeficiente.

How to cite: H. F. Campos, A. L. Bellon, E. R. Lara e Silva, and M. Villatore, "Eco-efficient concrete, optimized by particle packing models, with partial replacement of Portland cement by stone powder". Rev. IBRACON Estrut. Mater., vol. 15, no. 2, e15205, 2022, https://doi.org/10.1590/S1983-41952022000200005

\section{INTRODUCTION}

Civil construction has a high participation in the world economic and social, being the concrete its main input. However, this activity represents a major environmental impact, mainly in Portland cement (PC) production, which that may reach up to $5 \%$ to $7 \%$ of the global $\mathrm{CO}_{2}$ release [1]-[4]. These values are expected to increase to $30 \%$ by 2050 , if no action is taken [5]. The strategy used by PC producers to reduce the environmental impact involves promoting the production of cement types with lower clinker content. This strategy is based on the hypothesis that some additions, which are waste from other production chains, reach the cement industry with zero environmental impact [4], [6]-[12]. A material that has shown great potential for the replacement of PC is the waste generated during the aggregate production process in quarries: the stone powder (SP), due to its continuous granulometry, which contributes to the packing particles [13], [14]. This material typically remains stored in quarries as a waste material, obstructing the drainage of channels and generating dust during crushing operations. Apart from bringing greater profitability to companies, taking advantage of this SP would also benefit the environment.

In the same context, a subject studied by materials microstructure engineering that has the purpose of optimizing the concrete mixes reducing cement consumption without compromising mechanical performance, while still being ecological and economical is in the packing particles [15]. Concrete mixtures with better-accommodated particles tend to reduce the space required for filling with cement paste, demonstrating less PC consumption per $\mathrm{m}^{3}$ of concrete and theoretically indicating higher compressive strength [16]. Highly efficient packing reduces the intergranular voids in the paste through the combination of fines materials with different particle sizes and optimizes the granular skeleton of the aggregates to reduce paste consumption [17]. Additionally, particle packing optimization provides a guided replacement of fine materials to primarily control matrix fracture properties.

Particle packing models are divided into two main types: discrete and continuous. Discrete models consider multimodal distributions containing " $n$ " discrete size classes of particles rearrange by- themselves to reach the maximum packing density [3]. Some models, such as the compressible packing model (CPM), present good precision in their results [14]. This model defines the packing density of granular assemblies from the granulometric distribution and allows the consideration of the type of compaction applied. It also allows the consideration of aspects such as grain morphology, the presence of water and admixtures in an indirect manner since the packing density of each class of the grains component of mixtures must be determined experimentally. Recent studies have demonstrated the efficiency of this model in the production of high-strength and eco-efficient concretes [13], [17]. Conversely, continuous models consider continuously sized particles. Moreover, it assumes a similarity condition for particle packing; i.e. the array of particles (granulation image) surrounding every particle in the distribution should be similar, regardless the size of the particle [3].

The search for the ideal granulometric curve for the continuous models aroused the interest of several researchers in the early twentieth century. The first model, proposed by Fuller and Thompson [18], is a power curve that accounts for two variables: the distribution factor (q) and the largest particle size (D). The curve is described by Equation 1, with a distribution coefficient (q) equal to 0.5 to obtain a curve with minimum voids.

$$
\frac{C P F T}{100}=\left(\frac{d}{D}\right)^{q}
$$

where $\mathrm{CPFT}=$ the cumulative (volume) percent finer than $\mathrm{d}, \mathrm{d}=$ the particle diameter, $\mathrm{D}=$ the larger particle diameter, and $\mathrm{q}=$ the distribution coefficient.

Some researchers tried to improve this curve, like Andreasen and Andersen [19]. They proposed the use of an exponent $\mathrm{q}$ in the range of $0.33-0.50$. This adjustment factor $\mathrm{q}$ had to be determined experimentally and, therefore, can vary according to the characteristics of the particles. However, Ortega et al. [20] concluded that besides the above two parameters, the smallest particle size would also influence the packing density of granular systems. Therefore, in 1980, 
Funk and Dinger [21] improved Equation 1 by accounting for the smallest particle diameter (DS). The latter was defined as Alfred model and is presented by Equation 2. They proposed an adjustment factor $\mathrm{q}=0.37$, determined by computer simulations, which provides the maximum packing density.

$$
\frac{C P F T}{100}=\left(\frac{D P^{q}-D s^{q}}{D L^{q}-D S^{q}}\right)^{q}
$$

where CPFT $=$ the cumulative (volume) percent finer than DP, DP = the particle diameter, DL is the larger particle diameter, $\mathrm{Ds}=$ the smaller particle diameter, and $\mathrm{q}=$ the distribution coefficient.

Among the particle packing models, Alfred's is considered the one that best adapts to the real conditions of particle size distribution and is widely used in the manufacture of ceramics and porcelain tiles [22].

With the possibilities listed, research aimed at reducing $\mathrm{CO}_{2}$ emissions and the use of SP, optimized by particle packing models can add significant progress towards obtaining more eco-efficient concretes. In this context, the objective of the present study is evaluating the production of concretes with partial replacement of PC by SP, optimized by Alfred's particle packing model, seeking to reduce cement consumption and $\mathrm{CO}_{2}$ emissions per $\mathrm{MPa}$ of compressive strength .

\section{MATERIALS AND EXPERIMENTAL PROGRAM}

\subsection{Materials}

The PC used was the Brazilian cement type CP V-ARI, whose characteristics are described by the standard ABNT NBR 16697:2018 [23]. This type of cement is composed of up to $10 \%$ limestone filler in addition to the clinker. Its specific gravity is equal to $3,090 \mathrm{~kg} / \mathrm{m}^{3}$. The SP used is a waste material from the limestone sand production process. It was obtained from the quarry and then dried in a laboratory oven at $60^{\circ} \mathrm{C}$. Its specific gravity is equal to $2,670 \mathrm{~kg} / \mathrm{m}^{3}$. The SP was classified as inert according to the Brazilian standards that determine the pozzolanic activity with lime [24] and the performance index with PC [25]. Table 1 presents the chemical compositions of both materials, as obtained by the X-ray fluorescence (XRF) (Panalytical, model Axios Max with Rhodium tube $4 \mathrm{kV}$ ).

Table 1. X-ray fluorescence of the fine materials.

\begin{tabular}{|c|c|c|}
\hline \multicolumn{3}{|c|}{ Chemical composition } \\
\hline Parameter analyzed & PC & SP \\
\hline $\mathrm{Al}_{2} \mathrm{O}_{3}$ & $4.1 \%$ & $3.0 \%$ \\
\hline $\mathrm{SiO}_{2}$ & $18.7 \%$ & $6.1 \%$ \\
\hline $\mathrm{Fe}_{2} \mathrm{O}_{3}$ & $2.8 \%$ & $1.3 \%$ \\
\hline $\mathrm{CaO}$ & $60.6 \%$ & $48.6 \%$ \\
\hline $\mathrm{MgO}$ & $4.1 \%$ & $1.2 \%$ \\
\hline $\mathrm{SO}_{3}$ & $3.0 \%$ & $0.2 \%$ \\
\hline $\mathrm{CaO}$ free & $0.6 \%$ & - \\
\hline Insoluble residue & $0.7 \%$ & - \\
\hline Alkaline equivalent & $0.7 \%$ & - \\
\hline $\mathrm{K}_{2} \mathrm{O}$ & - & $0.6 \%$ \\
\hline $\mathrm{SrO}$ & - & $0.2 \%$ \\
\hline $\mathrm{Na}_{2} \mathrm{O}$ & - & $0.1 \%$ \\
\hline $\mathrm{TiO}_{2}$ & - & $0.1 \%$ \\
\hline $\mathrm{P}_{2} \mathrm{O}_{5}$ & - & $0.1 \%$ \\
\hline $\mathrm{Cl}$ & & - \\
\hline $\mathrm{MnO}$ & - & $<0.1 \%$ \\
\hline
\end{tabular}

In Table 1, it is evident that PC and the SP exhibit high calcium oxide content in their chemical compositions. Figure 1 presents the particle size distribution of the PC and the SP. The test was performed by laser diffraction (equipment Malvern 2000) after 1 minute of ultrasound. Artificial limestone sand $(\mathrm{S})$ and two limestone coarse aggregates were used: gravel with a 
maximum particle size equal to $9.5 \mathrm{~mm}$ (G9.5) and gravel with a maximum particle size equal to $19 \mathrm{~mm}$ (G19). The particle size distribution of the three aggregates, tested according to the standard ABNT NBR NM 248: 2003 [26] are also presented in Figure 1. The matrix rock of all aggregates is limestone. The characterization of the aggregates is shown in Table 2 according to: ABNT NBR NM 248: 2003 [26]; ABNT NBR NM 46: 2033 [27]; ABNT NBR NM 45: 2006 [28]; ABNT NBR NM 52: 2009 [29]; ABNT NBR NM 53: 2009 [30]; ABNT NBR 7211: 2009 [31].

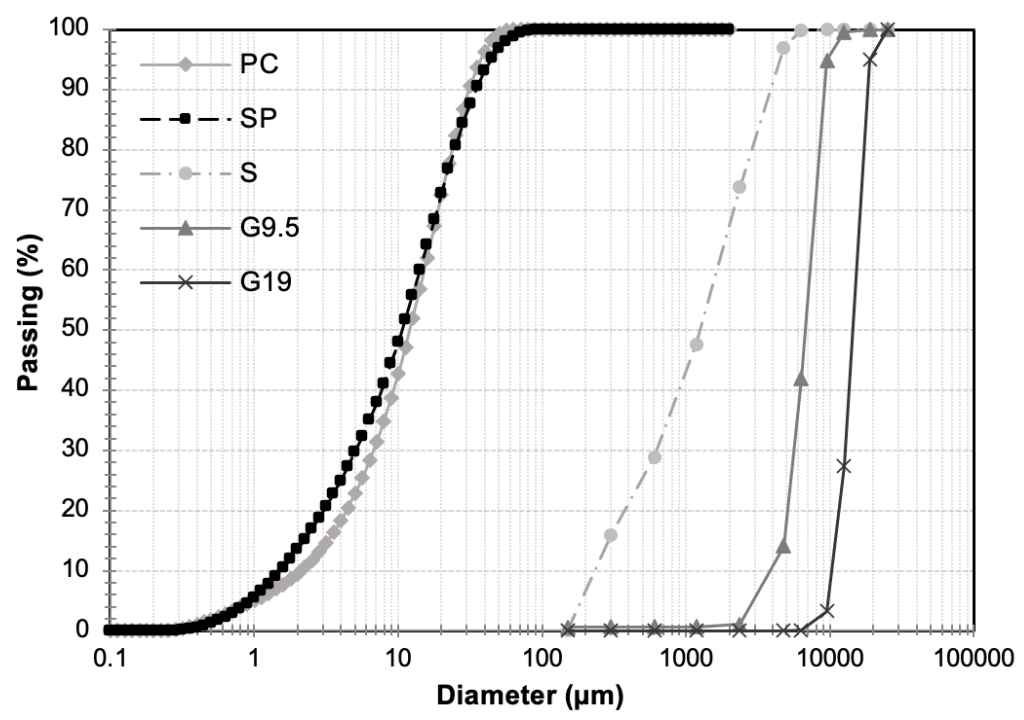

Figure 1. Particle size distribution of the materials.

Table 2. Physical characteristics of the aggregates.

\begin{tabular}{|c|c|c|c|c|}
\hline & PROPERTY & $\mathbf{S}$ & G9.5 & G19 \\
\hline Specific gravity $\left(\mathrm{g} / \mathrm{cm}^{3}\right)$ & $\begin{array}{c}\text { G9.5 and G19: ABNT NBR NM } 53 \text { (ABNT 2009b) S: } \\
\text { ABNT NBR NM } 52 \text { (ABNT 2009c) }\end{array}$ & 2.4 & 2.7 & 2.6 \\
\hline Bulk density $\left(\mathrm{g} / \mathrm{cm}^{3}\right)$ & \multirow{2}{*}{ ABNT NBR NM 45: 2006} & 1.8 & 1.5 & 1.5 \\
\hline Void index $(\%)$ & & 26.7 & 42.2 & 42.6 \\
\hline Material finer than $75 \mu \mathrm{m}(\%)$ & ABNT NBR NM 46: 2003 & 11.9 & 0.2 & 0.1 \\
\hline
\end{tabular}

S: Artificial limestone sand. G9.5: Gravel with a maximum particle size equal to $9.5 \mathrm{~mm}$. G19: Gravel with a maximum particle size equal to $19 \mathrm{~mm}$

As evident in Figure 1, the particle size distribution of the PC and the SP are continuous and like each other. The diameter D50 is equal to $12.0 \mathrm{~mm}$ for the PC and $10.6 \mathrm{~mm}$ for the SP. It was also noted that the coarse aggregates showed grain uniformity, which can be verified by the small slope of the granulometric curve. On the other hand, sand presents a more continuous distribution.

In Table 2, as expected, it is noted that the artificial limestone sand had the highest amount of material finer than $75 \mu \mathrm{m}$. Artificial sands tend to present granulometry different from natural ones, generally with a higher content of fines [13]. This artificial limestone sand was chosen because it is common in the region and it is an artificial sand, considering the environmental impact related to the extraction of natural sand. Informality in natural sand extraction processes aggravates the environmental impact of concrete production. As an alternative, replacing natural sand with artificial one reduces environmental impacts. In addition, its production is carried out in the quarries, which reduces transport costs. The amount of material finer than $75 \mu \mathrm{m}$ observed in the artificial limestone sand was high, thus helping to fill voids in the larger grains and, consequently, increasing the packing density. The same reasoning can be observed in G9.5, which obtained a powdery material content higher than that of G19.

The chemical admixture used consists of a third-generation superplasticizer with a density of $1,100 \mathrm{~kg} / \mathrm{m}^{3}$ and a solid content of $46.68 \%$, according to the manufacturer. It meets the requirements of ABNT NBR 11768: 2011 [32], being compatible with all types of Brazilian PC. Superplasticizer content was fixed at $0.9 \%$ relative to the weight of the solids. This value was obtained from the saturation dosage test [13]. 


\subsection{Experimental program}

To define the content of each material in the composition of the concretes, to reduce the empty spaces in the cementitious matrix and increase the compactness, the action of increasing the packing of the particles was adopted. This action was obtained through the more efficient distribution of the grain sizes of the materials and using a theoretical distribution model [17], [33]. The model adopted for the packing curve was Alfred's, according to Equation 2, with three different distribution-factors (q): 0.37; $0.21 ; 0.45$. As previously explained, the value of $q=0.37$, through experimental checks, has been shown to result in maximum particle packing [34]. The values below the value of $\mathrm{q}=0.37$ favor an increase in the amount of fines, while values above provide residual porosity. Thus, the lowest value analyzed $(q=0.21)$ seeks to evaluate the mixture with the highest content of fines. The highest value used $(q=0.45)$ intends to evaluate mixtures with lower levels of fine materials and the results in terms of efficiency (cement consumption/MPa), even knowing that in these mixtures, there is probably a lack of paste to involve the aggregates. With this discrepancy in values for the granulometric distribution module, it became possible to check the influence of fines on the flow between the particles and in terms of the efficiency of the produced concrete. For all mixtures, it was decided to keep the water/cement $(\mathrm{w} / \mathrm{c})$ constant and equal to 0.5 , with the expected resistance of about $31 \mathrm{MPa}$, due to the empirical relationship of Abrams' Law [35].

In the first mixture, only PC was considered as a fine material, without the use of SP, as a reference mixture and with the value $q=0.37$. From the second mixtures and for the others, the objective of the study was achieved with the partial replacement of CP by SP. SP was used as a PC partial replacement by percentage, since the particle size curve of the materials (Figure 1) were quite similar. The literature indicates the replacement content of $20 \%$ by mass as being ideal to produce more eco-efficient concretes [14], [17]. It is important to highlight that the models are applied in volume, since the packing is related to the spatial occupation by the particles in the composition, and not directly to its weight. Subsequently, applications will be made in weight, to ensure the necessary precision. Correlating with the appropriate specific gravity of the materials (section 2.1), in volume the substitution is equivalent to $22.4 \%$ of SP and $77.6 \%$ of PC.

For a better distribution of the theoretical curve, 15 different diameters were considered, the smallest in the series $10 \mu \mathrm{m}$ and the largest $19000 \mu \mathrm{m}$, considering the diameter through which $50 \%$ of the smallest particles pass (SP, with $\mathrm{D} 50=10.649 \mu \mathrm{m})$ and $50 \%$ of the largest particles $(\mathrm{G} 19$, with D50 $=19000 \mu \mathrm{m})$. Then, using Equation 2, the accumulated percentage of particles for each diameter of the series was determined. So that the proportion of each component material in the concrete could be defined, being divided into fines, sand, and coarse aggregate. Three distinct zones were considered in the model: a) fine materials: all material up to $100 \mu \mathrm{m}$; b) sand: from 100 to $4800 \mu \mathrm{m}$; c) coarse aggregates: from 4800 to $9500 \mu \mathrm{m}$ (G9.5) and the remaining G19 (up to $19000 \mu \mathrm{m}$ ). Other authors have also used this methodology in applying Alfred's model [11].

Table 3 shows the application of the model considering $q=0.37$.

Table 3. Application of the Alfred model with $q=0.37$.

\begin{tabular}{|c|c|c|c|c|}
\hline Diameter $(\mu \mathrm{m})$ & CPFT (\%) & Discrete (\%) & & \\
\hline 10 & $0 \%$ & $1 \%$ & \multirow{5}{*}{$11 \%$} & \multirow{5}{*}{$\mathrm{PC}$} \\
\hline 15 & $1 \%$ & $2 \%$ & & \\
\hline 30 & $3 \%$ & $3 \%$ & & \\
\hline 60 & $6 \%$ & $3 \%$ & & \\
\hline 100 & $9 \%$ & $2 \%$ & & \\
\hline 150 & $11 \%$ & $5 \%$ & \multirow{5}{*}{$46 \%$} & \multirow{5}{*}{$\mathrm{S}$} \\
\hline 300 & $16 \%$ & $7 \%$ & & \\
\hline 600 & $23 \%$ & $9 \%$ & & \\
\hline 1200 & $32 \%$ & $11 \%$ & & \\
\hline 2400 & $43 \%$ & $14 \%$ & & \\
\hline 4800 & $58 \%$ & $7 \%$ & \multirow{3}{*}{$27 \%$} & \multirow{3}{*}{ G9.5 } \\
\hline 6300 & $64 \%$ & $12 \%$ & & \\
\hline 9500 & $76 \%$ & $9 \%$ & & \\
\hline 12500 & $85 \%$ & $15 \%$ & \multirow{2}{*}{$15 \%$} & \multirow{2}{*}{ G19 } \\
\hline 19000 & $100 \%$ & $0 \%$ & & \\
\hline
\end{tabular}

Table 4 shows the application of the model with $\mathrm{q}=0.21$. 
Table 4. Application of the Alfred model with $\mathrm{q}=0.21$.

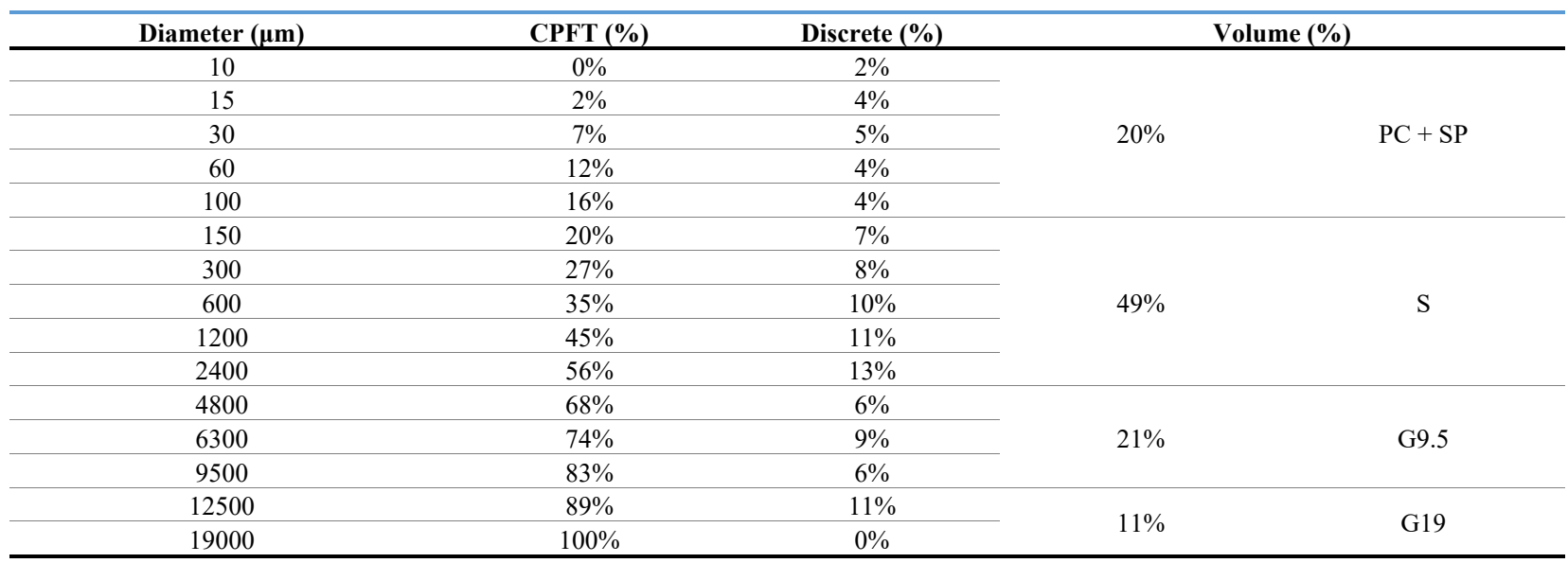

Table 5 presents the volumes obtained with the application of the model with $\mathrm{q}=0.45$.

Table 5. Application of the Alfred model with $\mathrm{q}=0.45$.

\begin{tabular}{|c|c|c|c|c|}
\hline Diameter $(\mu \mathrm{m})$ & CPFT (\%) & Discrete (\%) & & \\
\hline 10 & $0 \%$ & $1 \%$ & \multirow{5}{*}{$8 \%$} & \multirow{5}{*}{$\mathrm{PC}+\mathrm{SP}$} \\
\hline 15 & $1 \%$ & $2 \%$ & & \\
\hline 30 & $2 \%$ & $2 \%$ & & \\
\hline 60 & $4 \%$ & $2 \%$ & & \\
\hline 100 & $6 \%$ & $2 \%$ & & \\
\hline 150 & $8 \%$ & $4 \%$ & \multirow{5}{*}{$44 \%$} & \multirow{5}{*}{$\mathrm{S}$} \\
\hline 300 & $13 \%$ & $6 \%$ & & \\
\hline 600 & $18 \%$ & $8 \%$ & & \\
\hline 1200 & $26 \%$ & $11 \%$ & & \\
\hline 2400 & $37 \%$ & $15 \%$ & & \\
\hline 4800 & $52 \%$ & $7 \%$ & \multirow{3}{*}{$30 \%$} & \multirow{3}{*}{ G9.5 } \\
\hline 6300 & $59 \%$ & $13 \%$ & & \\
\hline 9500 & $72 \%$ & $10 \%$ & & \\
\hline 12500 & $82 \%$ & $18 \%$ & $18 \%$ & G19 \\
\hline
\end{tabular}

From each corresponding diameter and discrete percentage of particles, the curve of the model was done. It is shown in Figure 2 for all the q values $(0.37 ; 0.21 ; 0.45)$.

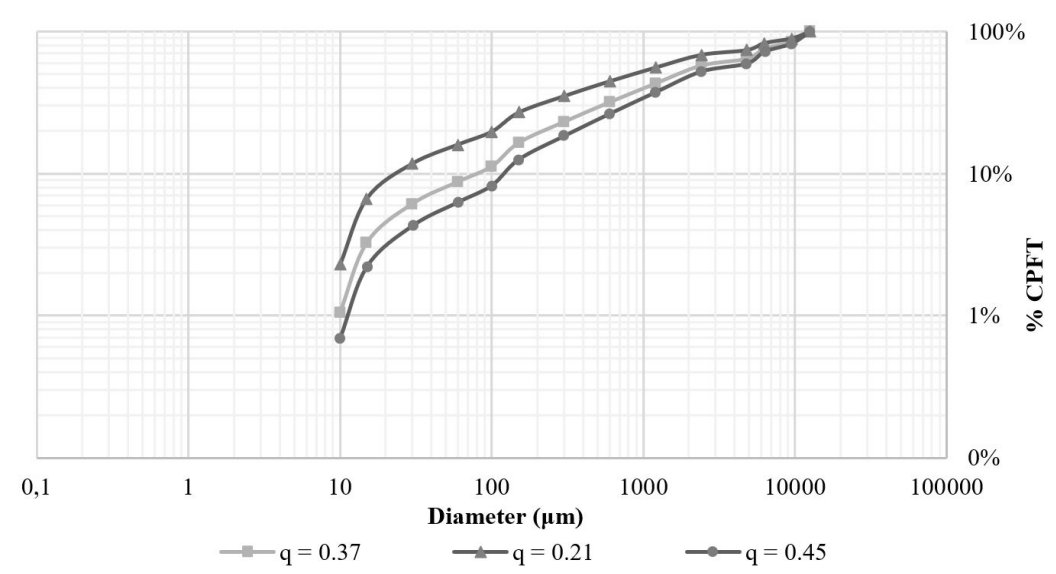

Figure 2. Particle size distribution curve for $\mathrm{q}=0.37, \mathrm{q}=0.21$ and $\mathrm{q}=0.45$. 
It is important to highlight the increase in the content of fines (PC and SP) evidenced by the lower value of q, from $11 \%$ with $\mathrm{q}=0.37$ (Table 3 ) to $20 \%$ with $\mathrm{q}=0.21$ (Table 4 ). The same occurred with the sand, from $46 \%$ ( $\mathrm{q}=0.37$ ) to $49 \%(\mathrm{q}=0.21)$. As for the coarse aggregates, the levels increased with the reduction of the value of $\mathrm{q}$, from $27 \%$ to $21 \%$ (G9.5) and $15 \%$ to $11 \%(\mathrm{G} 19)$. As expected, the increase in the q value ( $\mathrm{q}=0.45)$ caused a smaller volume of fines $(8 \%$ $\mathrm{PC}+\mathrm{SP}$ and $44 \% \mathrm{~S})$ and an increase in the content of coarse particles (30\% G9.5 and 18\% G19) in the mixture composition, as shown in Table 5 and Figure 2.

With the volume of different materials defined for each curve plotted, the study proceeded to effectively obtain the mixtures in weight. The ratio of PC to other materials was calculated in weight from the volume contents and the respective specific gravity. Equation 3 was used to calculate the $\mathrm{PC}$ per $\mathrm{m}^{3}$ of concrete, using the specific gravity of the materials that make up the concrete. The air content of $1.5 \%$ was considered, due to the packing of the particles, which provides a lower void content [13].

$$
C=\frac{1000-(\text { air } \% \times 10)}{\frac{1}{\gamma \mathrm{PC}}+\frac{a / c}{\gamma \text { water }}+\frac{a}{\gamma \text { sand }}+\frac{p}{\gamma \text { graves }}}
$$

where $\mathrm{C}=\mathrm{PC}$ content $\left(\mathrm{kg} / \mathrm{m}^{3}\right) ; \gamma=$ specific gravity; $\mathrm{a}=$ sand content, related to PC (PC: $\left.\mathrm{S}\right)$ in mass; $\mathrm{p}=$ graves content, related to $\mathrm{PC}(\mathrm{PC}: \mathrm{G})$ in mass.

Table 6 shows the consumption of materials in each mixture obtained with the application of the method.

Table 6. Consumption of materials in each mixture

\begin{tabular}{|c|c|c|c|c|c|}
\hline Mixture & \multicolumn{2}{|c|}{ Volume $\left(\mathrm{m}^{3}\right)$} & \multicolumn{2}{|c|}{ Content related to $\mathrm{PC}$} & \multirow{2}{*}{$\frac{\text { Weight (kg) }}{300.31}$} \\
\hline \multirow{6}{*}{ M1 } & $\mathrm{PC}$ & 0.11 & 1 & 1 & \\
\hline & $\mathrm{S}$ & 0.46 & 3.21 & $\mathrm{a}$ & 964.15 \\
\hline & G9.5 & 0.27 & 2.08 & \multirow{2}{*}{$\mathrm{p}$} & 623.45 \\
\hline & G19 & 0.15 & 1.16 & & 347.67 \\
\hline & Chemical admixture & 0.0025 & - & - & 2.7 \\
\hline & TOTAL & 1.00 & 6.44 & $\mathrm{~m}$ & - \\
\hline \multirow{7}{*}{ M2 } & PC & 0.09 & 1 & 1 & 240.32 \\
\hline & SP & 0.03 & 0.25 & & 59.94 \\
\hline & $\mathrm{S}$ & 0.46 & 4.14 & $\mathrm{a}$ & 994.25 \\
\hline & G9.5 & 0.27 & 2.68 & $\mathrm{p}$ & 642.91 \\
\hline & G19 & 0.15 & 1.49 & & 358.53 \\
\hline & Chemical admixture & 0.0020 & - & - & 2.7 \\
\hline & TOTAL & 1.00 & 8.30 & $\mathrm{~m}$ & - \\
\hline \multirow{7}{*}{ M3 } & PC & 0.15 & 1 & 1 & 390.07 \\
\hline & SP & 0.04 & 0.25 & & 97.29 \\
\hline & $\mathrm{S}$ & 0.49 & 2.48 & $\mathrm{a}$ & 967.75 \\
\hline & G9.5 & 0.21 & 1.17 & $\mathrm{p}$ & 458.12 \\
\hline & G19 & 0.11 & 0.59 & & 229.51 \\
\hline & Chemical admixture & 0.0032 & - & - & 4.39 \\
\hline & TOTAL & 1.00 & 4.24 & $\mathrm{~m}$ & - \\
\hline \multirow{7}{*}{ M4 } & $\mathrm{PC}$ & 0.06 & 1 & 1 & 181.60 \\
\hline & SP & 0.02 & 0.25 & & 45.29 \\
\hline & $\mathrm{S}$ & 0.44 & 5.36 & $\mathrm{a}$ & 973.48 \\
\hline & G9.5 & 0.30 & 4.02 & $\mathrm{p}$ & 729.63 \\
\hline & G19 & 0.18 & 2.36 & & 429.04 \\
\hline & Chemical admixture & 0.0015 & - & & 2.04 \\
\hline & TOTAL & 1.00 & 11.74 & $\mathrm{~m}$ & - \\
\hline
\end{tabular}

Comparing the consumption of each mix with the replacement of PC by SP, the use of $q=0.21$ resulted in a CP consumption $62 \%$ higher than the mixture with $\mathrm{q}=0.37$. For $\mathrm{q}=0.45$ consumption was close to $75 \%$ if also compared 
with the mix obtained with $\mathrm{q}=0.37$. Evidencing the higher and lesser amount of fines in the mixture by applying the Alfred model varying the q value.

The procedure used for mixing the materials to produce the concretes was adapted from Campos [13] and Damineli [5]. The first step consists of manual homogenization of the fine materials in the dry condition and their addition to a concrete mixer. Thereafter, half of the water and superplasticizer volumes are added to the concrete mixer in a constant and controlled flow for approximately 30 seconds with the mixing equipment on. The coarse aggregates are then added to the concrete mixer in a constant flow for approximately 1 minute, followed by 1.5 minutes of mixing time. The next step involves the addition of sand in a constant and controlled flow for 2.5 minutes. The addition of the remaining water and superplasticizer volumes is then performed in a controlled and constant flow for approximately 30 seconds with the mixing equipment on. Finally, the materials were mixed for 10 minutes, resulting in a 16-minute mixture.

After mixing, eight cylindrical specimens were molded for each concrete mix with dimensions of $100 \times 200 \mathrm{~mm}$ for the tests in a hardened state. The compaction was performed with a vibration table in four layers for 15 seconds each. The specimens were kept at the formworks at laboratory temperature for 24 hours and covered with a plastic film to prevent water loss. Thereafter, the concrete specimens were placed in a chamber with $>95 \%$ humidity and temperatures of $23 \pm 2{ }^{\circ} \mathrm{C}$ until the date of the test.

In the fresh state, specific gravity and consistency were determined. The specific gravity was obtained according to the procedure described in ABNT NBR 9833: 2008 [36]. The consistency was evaluated by the slump test, dictated by ABNT NBR NM 67: 1998 [37]. In the hardened state, the compressive strength test was carried out at 7 and 28 days, performed as established by ABNT NBR 5739: 2007 [38] with a ZwickRoell press with a capacity of 100 tons. The specimens were polished for the test using a concrete surface grinding machine. This process consists of the removal of a thin layer of top material by mechanical means.

The sustainability analyses were performed considering the $\mathrm{CO}_{2}$ emission factors obtained from the literature for each material used. Efficiencies were calculated considering the cement consumption and $\mathrm{CO}_{2}$ emissions required to obtain $1 \mathrm{MPa}$ of compressive strength, as proposed by Damineli et al. [39]. The emission factors used were obtained from the following references: PC: $0.863 \mathrm{kgCO}_{2} \mathrm{e} / \mathrm{kg}$ [40], [41]; SP: $0.0016 \mathrm{kgCO}_{2} \mathrm{e} / \mathrm{kg}$ [42]; S: $0.0016 \mathrm{kgCO}_{2} \mathrm{e} / \mathrm{kg}$ [42]; G9.5: $0.00155 \mathrm{kgCO}_{2} \mathrm{e} / \mathrm{kg}$ [43]; G19: $0.00155 \mathrm{kgCO}_{2} \mathrm{e} / \mathrm{kg}$ [43]; Chemical admixture: $1.133 \mathrm{kgCO}_{2} \mathrm{e} / \mathrm{kg}$ [44].

\section{RESULTS AND DISCUSSIONS}

Table 7 shows the specific gravity and the slump for each mixture.

Table 7. Results in fresh state

\begin{tabular}{cccccc}
\hline Mix & $\mathbf{q}$ & Specific gravity $\left(\mathbf{k g} / \mathbf{m}^{\mathbf{3}}\right)$ & $\mathbf{P C}\left(\mathbf{k g} / \mathbf{m}^{\mathbf{3}}\right)$ & Chemical admixture (\%) & Slump (mm) \\
\hline M1 & 0.37 & 2303.37 & 300.31 & 0.9 & 13.0 \\
\hline M2 & 0.37 & 2410.63 & 240.32 & 0.9 & 20.0 \\
\hline M3 & 0.21 & 2223.68 & 390.07 & 1.2 & $>250$ \\
\hline M4 & 0.45 & 2150.13 & 181.60 & 0.9 & - \\
\hline
\end{tabular}

The partial replacement of PC by SP in the composition allowed the reduction of cement consumption by $20 \%$, comparing the M1 and M2 mixtures, which have the same q value in the application of the method. However, the greater presence of SP fines demanded more water, which resulted in a lower slump (slump $=2.0 \mathrm{~cm}$ ), given that the $\mathrm{w} / \mathrm{c}$ ratio was kept constant, as observed in Table 7 . The demand for water is a function of the specific surface of the particles: the larger the specific surface of the particle, the more water will be needed to wet it, consequently the smaller the water layer thickness and workability. For the same amount of water, with a larger surface area, the thickness of the water film will be thinner and the flow capacity will be less and vice versa [45]. In addition, clusters of fine particles act as larger particles, which modifies the particle size distribution and hinders the mobility of flow lines, since clusters move more slowly and act as blocks to smaller particles, increasing viscosity and generating voids [5]. Other studies have also noted the loss of slump with the use of SP [13]. Still comparing mixtures M1 and M2, the greater specific gravity of the second indicates less voids content, therefore greater packing due to the fines of the SP.

In the M3, due to the lower q value, the loss of workability was even more pronounced, which resulted in the choice to increase the chemical admixture content to $1.2 \%$, increasing the slump. It is noteworthy that with the higher amount of PC and SP the larger the specific surface, therefore, requiring more water. To use the w/c ratio for all mixtures, the additive content was increased from 0.9 to $1.2 \%$ to avoid difficulties in molding the mixture. As a result, M3 was very viscous, with a slump greater than $25 \mathrm{~cm}$. 
The last mixture, with the highest value of q (0.45) obtained a higher volume of aggregates at the expense of fines and cement. The opposite occurred in M3, as q adopts values above 0.37 residual porosity [34] is verified, also evidenced by the low consumption of PC in the mixture. Mixture M4 lacked cement paste, not being enough to cover the aggregates, making them apparent. With the low consistency, it was not possible to measure the slump since the mixture disintegrated when removing the specimens. Also in Table 7, the specific gravity of M4 was the lowest obtained, which demonstrates the highest void content of this mixture, as expected by the q value used. Figure 3 shows the specimens one day after production, illustrating the highest void content in M4.

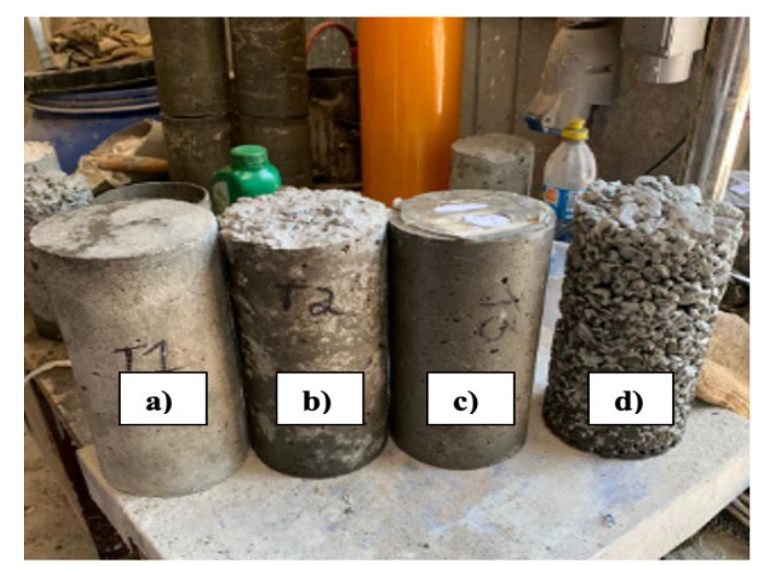

Figure 3. a) M1; b) M2; c) M3; d) M4.

Figures 4 show the results of compressive strength at 7 and 28 days.

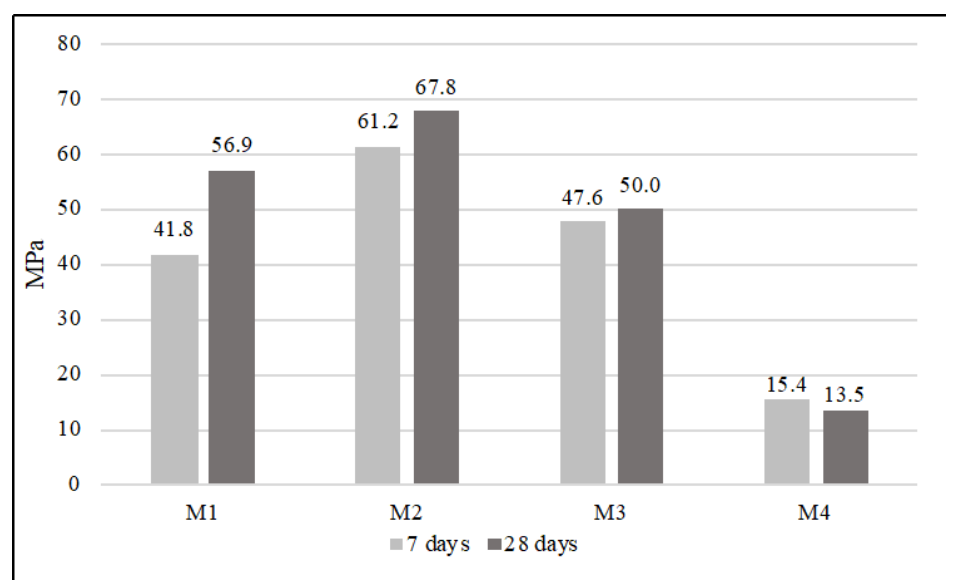

Figure 4. Compressive strength.

Figure 4 shows that, due to the use of high initial strength cement use, the values of compressive strength at 7 days proved to be high. Not only regarding the PC, but the application of the Alfred particle also packing model demonstrated the production of concretes with higher compressive strength than expected by Abrams's Law [35]. Only exception was M4, considering the $\mathrm{w} / \mathrm{c}$ ratio high for this compressive strength range $(\mathrm{w} / \mathrm{c}=0.50)$. Yousuf et al. also verified that concretes optimized by Alfred's model obtained compressive strengths above the target before 28 days [11]. To reach compressive strength close to $50 \mathrm{MPa}$, the w/c ratio around 0.40 is indicated [46]. The sole use of Abrams' law is not precise enough to predict the behaviour of highly packed systems designed using advanced techniques such as particle packing models [3]. The authors explain that particle packing models may enhance the particle size distribution of granular systems, reducing the material's porosity and consequently increasing the system packing density. Recent 
studies have shown that the use of particle packing models results in a reduction in concrete porosity, with a significant increase in concrete electrical resistivity and ultrasonic pulse velocities [14], [17]. Therefore, an increase in the compressive strength of the concrete is observed. So, the application of particle packing models, to increase the density of the granular system in cementitious materials, shows as a key parameter for obtaining concrete with high mechanical and durability performance [16].

It also can be seen, in Figure 4, that the mixture with the highest compressive strength was the M2, with $118 \%$ of the value expected by Abrams' Law [35]. It is also noted that the replacement the PC by SP in M2 provided greater compressive strength as compared to M1, for the same q value. Even though it is an inert material, the granulometric curve of the SP, and its amount of fines contributed to filling the voids, demonstrated by the compressive strength $19 \%$ higher than M2 compared to M1 with less PC consumption. This also indicates greater packing, as observed in other studies that used SP as a partial replacement for PC [13], [14], [17]. M3 obtained a PC consumption $62 \%$ higher than M2. However, its average compressive strength was $26 \%$ lower, proving that the greater packing (given by q=0.37) resulted in higher compressive strength, even with less PC consumption. Due to the lack of fines, M4 presented many voids and low compressive strength, being $80 \%$ lower than M2 with a 24\% lower PC consumption.

Figure 5 show the consumption of $\mathrm{PC}$ per $\mathrm{m}^{3}$ of concrete to obtain $1 \mathrm{MPa}$ of compressive strength, to analyze the efficiency of the mixtures produced.

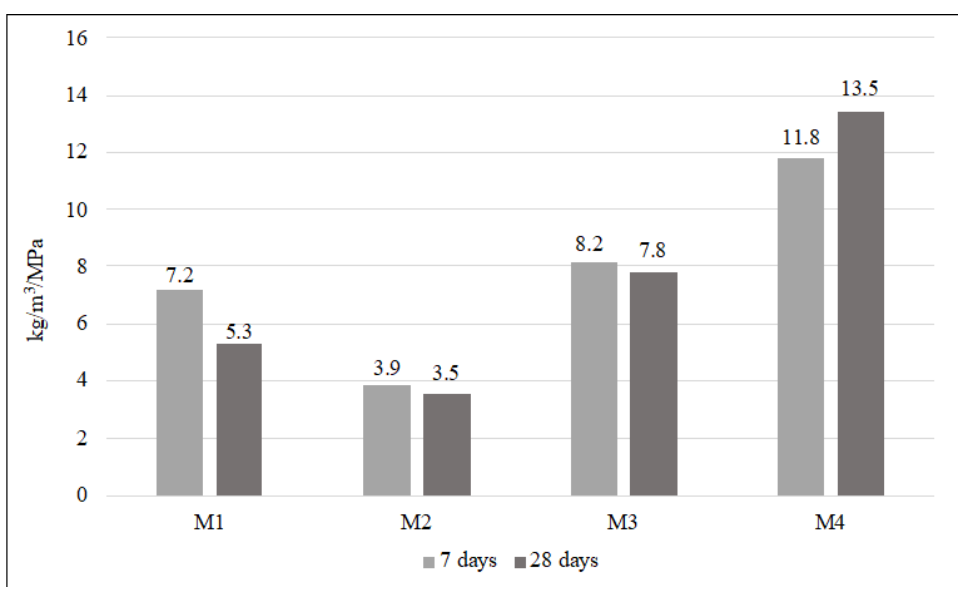

Figure 5. $\mathrm{kg} / \mathrm{m}^{3} / \mathrm{MPa}$.

It can be seen, in Figure 5, that M2 is the most efficient, with the lowest consumption of cement/MPa (3.5). Damineli et al. [39] showed that a large part of the Brazilian market for concretes, with most concretes produced in the range of $40 \mathrm{MPa}$ of compressive strength at 28 days, present the index above in the range between 7 and $14 \mathrm{~kg} / \mathrm{m}^{3} / \mathrm{MPa}$. The literature commonly presents values from 9 to $14 \mathrm{~kg} / \mathrm{m}^{3} / \mathrm{MPa}$ for conventional situations [3]. For high-performance concretes, the level is in the range of $5 \mathrm{~kg} / \mathrm{m}^{3} / \mathrm{MPa}$ [39]. Toralles et al. [47], to compare three mix methods for conventional concrete fixing the same desired compressive strength, show that for the ABCP (Brazilian Portland Cement Association) method the PC consumption of $418 \mathrm{~kg} / \mathrm{m}^{3}$ and w/c ratio of 0.49 reached $36.3 \mathrm{MPa}$. For the same w/c ratio, the O'Reilly method, with cement consumption of $412 \mathrm{~kg} / \mathrm{m}^{3}$, reached 36.5 MPa. Finally, the last method, from IPT (Institute of Technological Research), for a w/c ratio of 0.59 and cement consumption of $314 \mathrm{~kg} / \mathrm{m}^{3}$, obtained $27 \mathrm{MPa}$. For these mixtures, the binder index was between $7 \mathrm{and} 14 \mathrm{~kg} / \mathrm{m}^{3} / \mathrm{MPa}$, confirming the values indicated by Damineli et al. [39]. The most efficient concrete in this study, by the O'Reilly method, reached $11.29 \mathrm{~kg} / \mathrm{m}^{3} / \mathrm{MPa}$. Lopes [15] analyzed the application of Alfred's particle packing model in the production of optimized concretes, to reduce cement consumption. For comparison, the author opted to produce conventional and high strength concrete using the IPT and modified IPT methodologies. In the study, the concrete with the highest compressive strength, optimized by the Alfred model, resulting in $83.25 \mathrm{MPa}$ with cement consumption of $420.82 \mathrm{~kg} / \mathrm{m}^{3}$. The corresponding reference mixture, produced by the modified IPT method, presented $62.37 \mathrm{MPa}$ with cement consumption of $654.15 \mathrm{~kg} / \mathrm{m}^{3}$. The reference mixture had a binder index of $10.49 \mathrm{~kg} \mathrm{~m}^{3} / \mathrm{MPa}$ and the optimized one reached $5.05 \mathrm{~kg} \mathrm{~m}^{3} / \mathrm{MPa}$. Thus, it is noted that the most efficient mixture of the present study (M2) had lower cement consumption per MPa, compared with data from the literature.

The present study searched the production of optimized concretes in the compressive strength range of conventional ones, but with less consumption of PC necessary to reach this level. The compressive strength achieved by M1 and M2 
concretes put them at the same level as high-performance concretes. M1 presents a binder index close to $5 \mathrm{~kg} / \mathrm{m}^{3} / \mathrm{MPa}$. In M2, the partial replacement of PC by SP not only provided less cement consumption, but also greater packing and compressive strength gain, as previously mentioned exposed. As a result, M2 received a value of $3.5 \mathrm{~kg} / \mathrm{m}^{3}$ to deliver $1 \mathrm{MPa}$ of compressive strength, the lowest amount observed in the optimized concretes of the study. This value is $50 \%$ below the minimum value observed for conventional concretes $\left(7 \mathrm{~kg} / \mathrm{m}^{3} / \mathrm{MPa}\right)$ and $29 \%$ below that noted for highperformance concretes $\left(5 \mathrm{~kg} / \mathrm{m}^{3} / \mathrm{MPa}\right)$. Comparing M1 and M2 mixtures, the replacement of PC by SP in M2 allowed the reduction of the binder index by $45 \%$ at 7 days and by $32 \%$ at 28 days. Mixtures M3 and M4, the first for presenting the highest PC consumption between the mixtures and the second for the lowest compressive strength achieved, fit in the range of conventional concretes between 7 and $14 \mathrm{~kg} / \mathrm{m}^{3} / \mathrm{MPa}$.

Figure 6 shows the $\mathrm{kgCO}_{2} \mathrm{e}$ to produce $1 \mathrm{~m}^{3}$ of concrete.

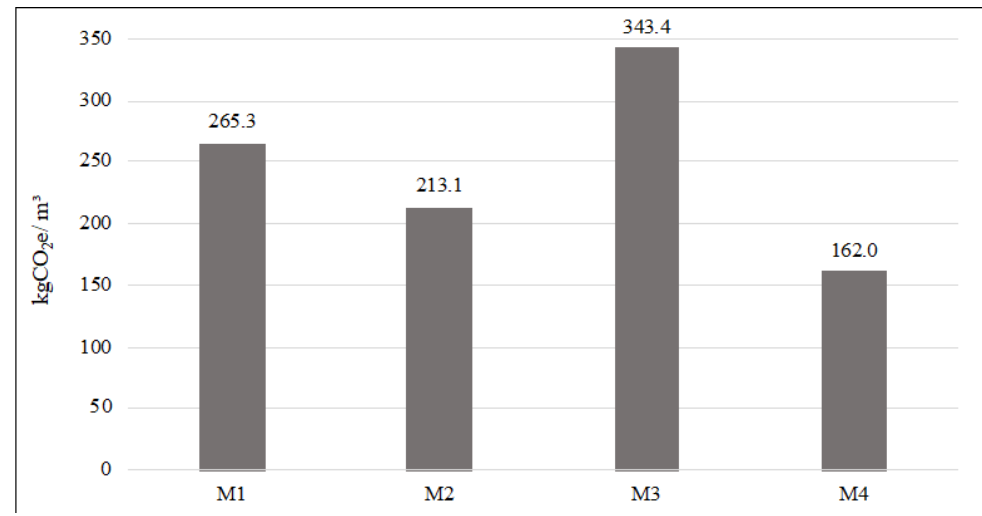

Figure 6. $\mathrm{kgCO}_{2} \mathrm{e} / \mathrm{m}^{3}$.

It can be seen, in Figure 6, that the mixture that presented the lowest emission index was M4. This fact is linked to its low PC consumption, predicted by the high q value uses (0.45), which represents a lower content of fines (PC+SP). M2 was in second place in this indicator, with M3 remaining in the sequence. Recalling that the q value was the same for the two mixtures $(\mathrm{q}=0.37$ for M1 and M2), only the replacement of PC by SP in M1 promoted a 20\% reduction in the $\mathrm{CO}_{2}$ emissions per $\mathrm{m}^{3}$ of concrete. $\mathrm{M} 3$, for presenting the highest amount of fines obtained the highest consumption of $\mathrm{PC}$ and, consequently, the highest indicator of emissions per $\mathrm{m}^{3}$.

Figure 7 shows the efficiency of the concretes in terms of $\mathrm{CO}_{2}$ emissions.

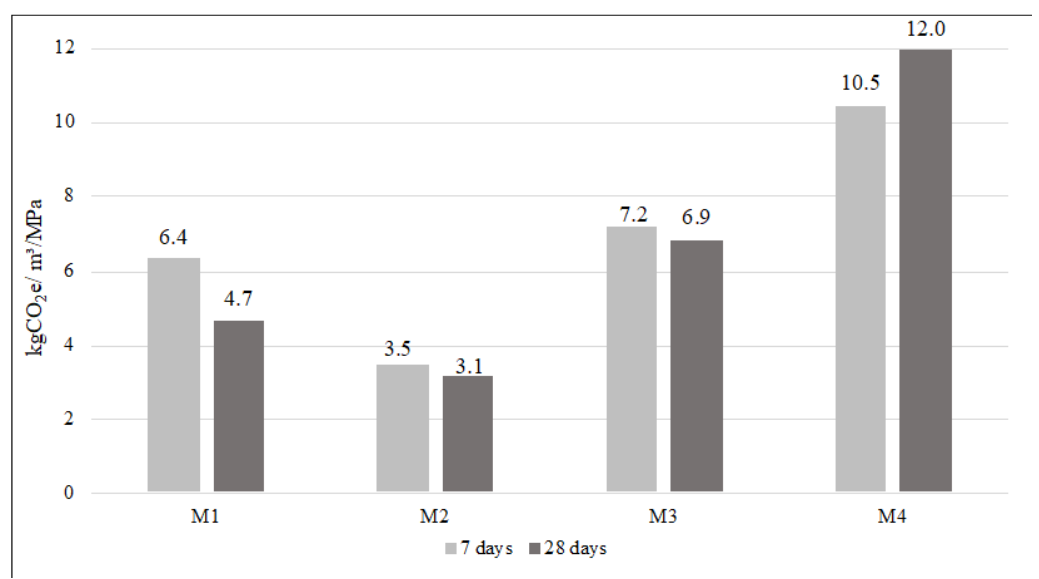

Figure 7. $\mathrm{kg} \mathrm{CO}_{2} \mathrm{e} / \mathrm{m}^{3} / \mathrm{MPa}$. 
It as can be seen in Figure 7, that M4, which obtained the lowest emissions per $\mathrm{m}^{3}$, now attests to the worst performance due to its low targeted compressive strength. Again, when comparing M1 and M2, the replacement by SP in the second mixture resulting in lower PC consumption and higher compressive strength, resulted in a $33 \%$ reduction in $\mathrm{kgCO}_{2} \mathrm{e} / \mathrm{m}^{3} / \mathrm{MPa}$. The measured compressive strength of $\mathrm{M} 3$ was satisfactory when compared to conventional concretes. However, the consumption of PC higher than the other produced mixes made it intermediate in relation to this index over the others, being 54\% above M2 (most efficient). In Costa's research [48], the author raised quantities of $\mathrm{CO}_{2}$ emitted in the production of materials used in civil construction. Concretes produced with $\mathrm{CP} V \mathrm{ARI}$ in the range of $50 \mathrm{MPa}$ with a standard mixture of cement consumption close to $400 \mathrm{~kg} / \mathrm{m}^{3}$, it would take the level of emissions at $485 \mathrm{kgCO}_{2} \mathrm{e} / \mathrm{m}^{3}$, witch results in $9.7 \mathrm{kgCO}_{2} \mathrm{e} / \mathrm{m}^{3} / \mathrm{MPa}$. It is noted that the values obtained in the present research were satisfactory, with the best concrete produced (M2) reaching $213.09 \mathrm{kgCO}_{2} \mathrm{e} / \mathrm{m}^{3}$ and $3.15 \mathrm{kgCO}_{2} \mathrm{e} / \mathrm{m}^{3} / \mathrm{MPa}$.

\section{CONCLUSIONS}

After performing the experiments and analyzing the obtained results, the following conclusions can be made:

- The application of the method resulted in concretes with cement consumption of $300.31 \mathrm{~kg} / \mathrm{m}^{3}$ for M1 $(\mathrm{q}=0.37$ without replacing PC by SP), $240.32 \mathrm{~kg} \mathrm{~m}^{3}$ for M2 ( $\mathrm{q}=0.37$ with the replacement of PC by SP), $390.07 \mathrm{~kg} / \mathrm{m}^{3}$ for $\mathrm{T} 3(\mathrm{q}=0.21)$ and $181.60 \mathrm{~kg} / \mathrm{m}^{3}$ for $\mathrm{T} 4(\mathrm{q}=0.45)$.

- In the fresh state, the slump was reduced in the mixtures with the replacement of PC by SP due to the higher content of fines in the SP. These fines result in a greater specific surface; therefore, more water was needed to wet the particles, consequently, the water layer thickness and workability were smaller. On the other hand, the use of SP, due to the greater packing provided by the fines of its composition, increased the specific gravity comparing M1 (without SP) and M2 (with replacement of $20 \%$ of PC by SP). In the third mixture (M3), due to the lower q value (0.21), the loss of workability was even more accentuated. It is noteworthy that with the greater amount of PC and SP composing the mixture, the larger the specific surface, therefore, requiring more water. To use the same w/c ratio for all mixtures, the additive content was increased from 0.9 to $1.2 \%$ to avoid difficulties in molding the specimens. As a result, M3 was very viscous, with a slump greater than $25 \mathrm{~cm}$. In the last mixture (M4), with the highest $\mathrm{q}$ value (0.45), residual porosity was noted. This feature exhibited little paste, not enough to cover the aggregates. With the low consistency, it was not possible to measure the slump.

- In the hardened state, the M2 mixture showed the highest compressive strength - $67.8 \mathrm{MPa}$ at 28 days. Comparing the M1 and M2 mixtures $(q=0.37)$, the first without and the second with the partial replacement of PC by SP, the modified mixture showed higher compressive strength, indicating that the SP favored greater packing. Even though it is an inert material, the SP allowed 19\% higher compressive strength with $20 \%$ less PC consumption. M3 $(q=0.21)$ presented compressive strength $16 \%$ below M2 $(q=0.37)$, for a $62 \%$ higher PC consumption. This fact demonstrating that the value $\mathrm{q}=0.37$ resulted in greater packing and, consequently, higher compressive strength, even with less PC consumption. M4 had the lowest compressive strength of the mixtures, due to the lower consumption of PC and higher voids content. The application of the Alfred particle packing obtained highest compressive strength than expected (31 MPa), except for $\mathrm{T} 4$, considering the high $\mathrm{w} / \mathrm{c}$ ratio used $(\mathrm{w} / \mathrm{c}=0.50)$.

- In terms of efficiency, the M2 binder index, which showed the best results, was $3.5 \mathrm{~kg} / \mathrm{m}^{3} / \mathrm{MPa}$, lower than the values observed in the literature. M1 presented a binder index 48\% above M2 due to its higher CP consumption and lower compressive strength, both factors are related to the partial replacement of $\mathrm{PC}$ by SP. As cement is the component material of concrete that most emanates $\mathrm{CO}_{2}$ emissions for its production, the lower consumption of cement in the mix implies lower $\mathrm{CO}_{2} \mathrm{e}$ emissions per $\mathrm{m}^{3}$ of concrete. Thus, the mixture that presented the lowest emission values per $\mathrm{m}^{3}$ was M4. However, in terms of efficiency, M2 proved to be the most eco-efficient, with only $3.15 \mathrm{kgCO}_{2} / \mathrm{m}^{3} / \mathrm{MPa}$.

It is concluded then that the method proved to be simple to be applied, providing a lower volume of voids in the concrete that resulted in less consumption of paste needed to fill these spaces. Consequently, it was possible to produce concrete with lower cement consumption and $\mathrm{CO}_{2}$ emissions per MPa. SP as a partial replacement for PC provided greater compressive strength, even though it is an inert material. Sustainable concretes proved to be very efficient, with a lot of potential yet to be explored. So, as a suggestion for future work: verify the method by applying other residual materials in substitution of PC; evaluate the rheological parameters of concretes optimized by the particle packing technique.

\section{ACKNOWLEDGEMENTS}

The authors would like to thank the companies Itambe and Grace which kindly provided all necessary materials for the study. The company Votorantim Cimentos, for carrying out the compressive strength test of the studied concrete. 
We also thank the Department of Construction Engineering (DCC) and the Post-graduation Program in Civil Engineering at the Federal University of Parana (PPGEC/UFPR) for the infrastructure support provided.

\section{REFERENCES}

[1] M. L. Berndt, "Influence of concrete mix design on CO2 emissions for large wind turbine foundations," Renew. Energy, vol. 83, pp. 608-614, 2015, http://dx.doi.org/10.1016/j.renene.2015.05.002.

[2] K. Celik, C. Meral, P. A. Gursel, P. Mehta, A. Horvath, and P. Monteiro, "Mechanical properties, durability, and life-cycle assessment of self-consolidating concrete mixtures made with blended portland cements containing fly ash and limestone powder," Cement Concr. Compos., vol. 56, pp. 59-72, 2015, http://dx.doi.org/10.1016/j.cemconcomp.2014.11.003.

[3] M.T. Grazia, L.F.M. Sanchez, R.C.O. Romano, and R.G. Pileggi, "Investigation of the use of continuous particle packing models (PPMs) on the fresh and hardened properties of low-cement concrete (LCC) systems," Constr. Build. Mater., v. 195, p. 524-536, 2019, https://doi.org/10.1016/j.conbuildmat.2018.11.051.

[4] Sindicato Nacional da Indústria do Cimento, ROADMAP Tecnológico do Cimento: Potencial de Redução das Emissões de Carbono da Indústria do Cimento Brasileira até 2050. Rio de Janeiro: SNIC, 2019.

[5] B. L. Damineli, "Conceitos para formulação de concretos com baixo consumo de ligantes: controle reológico, empacotamento e dispersão de partículas," M.S. thesis, Esc. Politéc., Univ. São Paulo, São Paulo, 2013.

[6] T. Proske, S. Hainer, M. Rezvani, and C. Graubner, "Eco-friendly concretes with reduced water and cement contents - Mix design principles and laboratory tests," Cement Concr. Res., vol. 51, pp. 38-46, 2013, http://dx.doi.org/10.1016/j.cemconres.2013.04.011.

[7] T. Higuchi, M. Morioka, I. Yoshioka, and K. Yokozeki, "Development of a new ecological concrete with $\mathrm{CO}_{2}$ emissions below zero," Constr. Build. Mater., vol. 67, pp. 338-343, Sep 2014, http://dx.doi.org/10.1016/j.conbuildmat.2014.01.029.

[8] E. Gartner and H. Hirao, "A review of alternative approaches to the reduction of $\mathrm{CO}_{2}$ emissions associated with the manufacture of the binder phase in concrete," Cement Concr. Res., vol. 78, pp. 126-142, 2015, http://dx.doi.org/10.1016/ j.cemconres.2015.04.012.

[9] R. C. D. O. Romano, D. D. R. Torres, and R. G. Pileggi, "Impact of aggregate grading and air-entrainment on the properties of fresh and hardened mortars," Constr. Build. Mater., vol. 82, pp. 219-226, 2015, http://dx.doi.org/10.1016/j.conbuildmat.2015.02.067.

[10] H. S. Mueller, M. Haist, J. S. Moffatt, and M. Vogel, "Design, material properties and structural performance of sustainable concrete," Procedia Eng., vol. 171, pp. 22-32, 2017, http://dx.doi.org/10.1016/j.proeng.2017.01.306.

[11]S. Yousuf, L. F. M. Sanchez, and S. A. Shammeh, "The use of particle packing models (PPMs) to design structural low cement concrete as an alternative for construction industry," J. Build. Eng., v. 25, p. 100815, Sep. 2019, https://doi.org/ 10.1016/j.jobe.2019.100815.

[12] P. R. Matos, R. D. Sakata, and L. R. Prudêncio Jr., "Eco-efficient low binder high-performance self-compacting concretes," Constr. Build. Mater., vol. 225, pp. 941-955, 2019, http://dx.doi.org/10.1016/j.conbuildmat.2019.07.254.

[13] H. F. Campos, "Dosagem de concreto sustentável e de alta resistência, otimizada por modelos de empacotamento de partículas, com substituição parcial do cimento Portland por pó de pedra e sílica ativa," M.S. thesis, Univ. Fed. Paraná, Curitiba, Brazil, 2019.

[14] H. F. Campos, N. S. Klein, J. Marques Fo., and M. Bianchini, "Low- cement high-strength concrete with partial replacement of Portland cement with stone powder and silica fume designed by particle packing optimization," J. Clean. Prod., vol. 261, pp. 121228, 2020, http://dx.doi.org/10.1016/j.jclepro.2020.121228.

[15] H. M. T. Lopes, "Aplicação do conceito de empacotamento de partículas na otimização de dosagem de concretos de cimento Portland," M.S. thesis, Universidade Federal de São Carlos, São Carlos, São Paulo, Brazil, 2019.

[16] A. Castro and F. Ferreira, "Effect of particle packing in the durability of high performance concretes," Ing. Constr., vol. 31, no. 2, pp. 91-104, 2016.

[17]H.F. Campos, J Marques Fo, and N.S. Klein, "Proposed mix design method for sustainable high-strength concrete using particle packing optimization," J. Clean. Prod., vol. 265, pp. 121907, 2020, https://doi.org/10.1016/j.jclepro.2020.121907

[18] W. B. Fuller and S. E. Thompson, "The laws of proportioning concrete," in Transactions of ASCE, 1907, pp. 67-143.

[19] A. H. M. Andreasen and J. Andersen, "Über die Beziehungzwischen Kornabstufung und Zwischenraum in Produktenauslosen Körnern (miteinigen Experimenten)," Colloid Polym. Sci., vol. 50, pp. 217-228, 1930.

[20] F. D. S. Ortega, R. G. Pileggi, P. Sepúlveda, and V. C. Pandolfelli, "Influência dos modelos de Alfred e de Andreasen sobre a microestrutura e densidade a verde de compactos cerâmicos obtidos por colagem ou prensagem," Ceramica, vol. 43, no. 283-284, pp. 185-191, 1997, http://dx.doi.org/10.1590/S0366-69131997000400007.

[21]J. E. Funk and D. R. Dinger, Grinding and Particle Size Distribution Studies for Coal-Water Slurries at High Solids Content, Final Report. New York, USA: Empire State Electric Energy Research Corporation (ESEERCO), 1980.

[22] I. R. Oliveira, A. R. Studart, R. G. Pileggi, and V. C. Pandolfelli, Dispersão e Empacotamento de Partículas: Princípios e Aplicações em Processamento Cerâmico, São Paulo: Fazendo Arte, 2000, pp. 224.

[23] Associação Brasileira de Normas Técnicas, Cimento Portland-Requisitos, NBR 16697, 2018. 
[24] Associação Brasileira de Normas Técnicas, Materiais pozolanicos - Determinacao da Atividade Pozolanica com Cal aos Sete Dias, NBR 5751, 2015.

[25] Associação Brasileira de Normas Técnicas, Materiais pozolânicos - Determinação do Índice de Desempenho com Cimento Portland aos 28 dias, NBR 5752, 2014.

[26] Associação Brasileira de Normas Técnicas, Agregados - Determinação da Composição Granulométrica, NBR NM $248,2003$.

[27] Associação Brasileira de Normas Técnicas, Agregados - Determinação do Material Fino que Passa Através da Peneira 75 um, por Lavagem, NBR NM 46, 2003.

[28] Associação Brasileira de Normas Técnicas, Agregados - Determinação da Massa Unitária e do volume de vazios, NBR NM 45, 2006.

[29] Associação Brasileira de Normas Técnicas, Agregado miúdo - Determinação de Massa Específica e Massa Específica Aparente, NBR NM 52, 2009.

[30] Associação Brasileira de Normas Técnicas, Agregado graúdo - Determinação de Massa Específica, Massa Especifica Aparente e Absorção de Água, NM 53, 2009.

[31] Associação Brasileira de Normas Técnicas, Agregados para Concreto - Especificação, NBR 7211, 2009.

[32] Associação Brasileira de Normas Técnicas, Aditivos para Concreto de Cimento Portland, NBR 11768, 2011.

[33] R. Yu, P. Spiesz and H. J. H. Brouwers, "Development of an eco-friendly Ultra-High Performance Concrete (UHPC) with efficient cement and mineral admixtures uses," Cement Concr. Compos., vol. 55, pp. 383-394, 2015, http://dx.doi.org/10.1016/j.cemconcomp.2014.09.024.

[34] A. L. Castro and V. C. Pandolfelli, "Revisão: conceitos de dispersão e empacotamento de partículas para a produção de concretos especiais aplicados na construção civil," Ceramica, vol. 55, no. 333, pp. 18-32, 2009, http://dx.doi.org/10.1590/S036669132009000100003.

[35] D. A. Abrams, Design of Concrete Mixtures. Chicago, USA: Structural Materials Research Laboratory, 1924.

[36] Associação Brasileira de Normas Técnicas, Concreto Fresco - Determinação da Massa Específica, do Rendimento e do Teor de Ar pelo Método Gravimétrico, ABNT NBR 9833, 2009.

[37] Associação Brasileira de Normas Técnicas, Concreto - Determinação da Consistência pelo Abatimento do Tronco de Cone, ABNT NBR NM 67, 1998.

[38] Associação Brasileira de Normas Técnicas, Concreto - Ensaio de Compressão de Corpos-de-prova Cilíndricos, ABNT NBR 5739, 2007.

[39] B. L. Damineli, F. M. Kemeid, P. S. Aguiar, and V. M. John, "Measuring the eco-efficiency of cement use," Cement Concr. Compos., vol. 32, no. 8, pp. 555-562, 2010.

[40] V. C. H. C. Oliveira, "Estratégias para a minimização da emissão de CO2 de concretos estruturais," M.S. thesis, Escola Politécnica da Universidade de São Paulo, São Paulo, Brazil, 2015.

[41] Votorantim Cimentos, EPD - Environmental Product Declaration. Portland, USA: PCA, 2016.

[42] C. M. B. D. B. Falcão, Análise da Qualidade do Investimento e Emissões de $\mathrm{CO}_{2}$ Associadas à Produção de Agregados Reciclados na Região Metropolitana de São Paulo. São Paulo: Escola Politécnica, Universidade de São Paulo, 2013.

[43] E. Rossi, "Avaliação do ciclo de vida da brita para a construção civil: estudo de caso," M.S. thesis, Universidade Federal de São Carlos, São Carlos, Brazil, 2013.

[44] F. Ma, A. Sha, P. Yang, and Y. Huang, "The greenhouse gas emission from portland cement concrete pavement construction in China," IJERPH., vol. 13, no. 7, pp. 632, 2016. https://doi.org/10.3390/ijerph13070632.

[45] L. G. Li and A. K. H. Kwan, "Concrete mix design based on water film thickness and paste film thickness," Cement Concr. Compos., vol. 39, pp. 33-42, 2013, http://dx.doi.org/10.1016/j.cemconcomp.2013.03.021.

[46] B. F. Tutikian and P. Helene, "Dosagem dos concretos de cimento Portland," in Concreto: Ciência e Tecnologia, G. C. Isaia, Ed., São Paulo: Ibracon, 2011.

[47] B. M. Toralles et al., "Estudo comparativo de diferentes métodos de dosagem de concretos convencionais," Rev. Eng. Tecnol., vol. 10, no. 1, pp. 184-198, 2018.

[48] B. L. C. Costa, "Quantificação das emissões de $\mathrm{CO}_{2}$ geradas na produção de materiais utilizados na construção civil," M.S. thesis, Universidade Federal do Rio de Janeiro, Rio de Janeiro, 2012.

Author contributions: HFC.: Conceptualization (Lead), Formal analysis (Equal), Investigation (Equal), Methodology (Lead), Project administration (Lead), Supervision (Lead), Writing (Lead); ALB: Formal analysis (Equal), Investigation (Equal), Methodology (Equal), Validation (Equal), Writing (Supporting). ERDLS.: Formal analysis (Equal), Investigation (Equal), Methodology (Equal), Writing (Supporting). VMVJ: Formal analysis (Equal), Investigation (Equal), Methodology (Equal), Writing (Supporting).

Editors: Bernardo Tutikian, Guilherme Aris Parsekian. 